\title{
Local Practices and Knowledge Associated with Date Palm Cultivation in Southeastern Niger
}

\section{Oumarou Zango ${ }^{1,2,3}$, Hervé Rey ${ }^{1}$, Yacoubou Bakasso², René Lecoustre ${ }^{1}$, Frédérique Aberlenc ${ }^{4}$, Jean-Christophe Pintaud4}

${ }^{1}$ UMR AMAP, CIRAD, Montpellier, France

${ }^{2}$ Faculty of Sciences and Technologies, University of Niamey, Niamey, Niger

${ }^{3}$ Montpellier University, Montpellier, France

${ }^{4}$ F2F-Palms Group, UMR DIADE, IRD, Montpellier, France

Email: zangooumarou@gmail.com

How to cite this paper: Zango, O., Rey, H., Bakasso, Y., Lecoustre, R., Aberlenc, F. and Pintaud, J.-C. (2016) Local Practices and Knowledge Associated with Date Palm Cultivation in Southeastern Niger. Agricultural Sciences, 7, 586-603.

http://dx.doi.org/10.4236/as.2016.79056

Received: July 7, 2016

Accepted: September 10, 2016

Published: September 14, 2016

Copyright $\odot 2016$ by authors and Scientific Research Publishing Inc. This work is licensed under the Creative Commons Attribution International License (CC BY 4.0).

http://creativecommons.org/licenses/by/4.0/

\begin{abstract}
The date palm (Phoenix dactylifera L.), a dioecious species, is of particular interest in the Sahel due to its phenological plasticity in relation to climate change and its double-flowering capacity. This article explores local practices and knowledge associated with date palm cultivation in the oasis basins of southeastern Niger, and provides an inventory of local seed propagated varieties, for more effectively guiding agricultural research and the breeding of this species. We carried out a survey of 30 date palm growers in 14 villages of the Manga region. The qualitative data of the survey were processed by a Multiple Correspondence Analysis. We inventoried 19 date palm varieties, for which the main distinctive criterion was fruit colour, but some other criteria such as biology or provenance were also used. The cultural practices and knowledge associated with the date palm in Manga have improved since the 1990s. They also depend on ethnic groups and the importance they assign to farming compared to livestock rearing and trading activities. The type of basin (high, intermediate, or low water table) influences growers' practices and perceptions. Lastly, the date harvest in the wet season is abundant, but of mediocre quality, whereas it is the opposite for the dry season harvest. To conclude, sustainable development of date palm cultivation in the Sahel zone relies firstly on the selection of varieties that are early fruit producers or that can complete fruit maturation during the raining season and secondly on technical capacity building for producers.
\end{abstract}

\section{Keywords}

Sahel, Phoenix dactylifera, Seed Propagated Variety, Local Knowledge, Climate Change 


\section{Introduction}

The Sahel (a semi-arid zone) is acknowledged to be a climate change hot spot with great social and environmental vulnerability [1]. Farming in the Sahel countries needs to deal with this change in order to meet the food security of their growing populations. Using plant species with high phenological plasticity (ability to adapt), such as the date palm (Phoenix dactylifera L., [2] [3]), is one response to difficult pedoclimatic conditions to which few plants are adapted.

The date palm is a multi-purpose plant [4]. Its ecosystem services enable the development of diverse forms of animal and plant life essential for the populations of arid zones [5]. This dioecious species, mainly grown for its fruits, is of great socio- economic importance on the Arabian Peninsula, in North Africa and in the Middle East [6]-[8]. It has been introduced into many regions of the world, including Asia, Australia, the USA and Spain, and it is present in the Sahel, notably in Niger, Mali, Chad, Mauritania and Djibouti [9] [10].

In Niger, the date palm is cultivated in two zones, one traditional in the Sahara and the other more marginal in the Sahel. The traditional zone stretches to the North, to Mount Air and into the Ingal valley, and to the Northeast, in the Bilma region on the Djado plateau, Kawar and Agram. The marginal Sahel zone, to the Southeast, covers Damagaran (Zinder region) and Manga (Diffa region; [11]. In southeastern Niger, the date palm stand is made of a few hundred or thousand plants in oasis basins [12]. The introduction of the date palm there would appear to date from the turn of the 20th century; the unexpected consequences of the great famine "Gande beeri" in 1913-1914 [13] led the population of Manga to understand that the date palm could be part of agricultural diversification to contribute to household food security. However, farmers did not show any more interest in it until the 1970s, when the climate became even more arid [14]. In southeastern Niger, as in the Thar desert in western India [15], the palms produce dates twice a year: an initial atypical season from September to March which would seem to involve under $20 \%$ [16] of mature palms and produce dry dates, and a second season of typical production from January to June, which involves virtually all bearing palms [16] whose date ripening is disrupted by the onset of the rainy season [12] [15]. In general, the dates produced in southeastern Niger, as in the Thar desert in western India, are of lower commercial value and storage quality [12] than dates from the traditional zones, such as Bilma in northern Niger, Algeria and Libya.

Better knowledge of local varietal diversity of the date palm in southeastern Niger and of the associated local knowledge would make it possible to more effectively guide agricultural research requirements on this species with high phenological plasticity, in view of the consequences of climate change for the Sahel. Indeed, in order to reduce the damage caused by the early onset of rainfall and improve the commercial value and storage quality of dates, it might be worth promoting seed propagated varieties that start bearing early, or can complete fruit maturation during the raining season, or focusing on the first harvest. However, these seed propagated varieties had not been inventoried; nor had the associated knowledge and farming practices. It was in order to 
fill that gap in the inventory that we investigated these local practices and knowledge and we inventoried the date palm seed propagated varieties in the oasis basins of the Manga region in southeastern Niger. The study was completed by looking at the use made of income generated by this crop.

\section{Materials and Methods}

\subsection{Study Site and Survey Procedure}

Our study was undertaken from May to November 2014 in southeastern Niger, in the two departments of the Manga region (latitude $13^{\circ} 20^{\prime} \mathrm{N}$ to $13^{\circ} 55^{\prime} \mathrm{N}$; longitude $9^{\circ} 50^{\prime} \mathrm{E}$ to $11^{\circ} 50^{\prime} \mathrm{E}$ ): Gouré and Goudoumaria (Figure 1). The inhabitants of Manga are primarily Kanuri sedentary agropastoralists, along with some Hausa commercial farmers and Fulani, Toubou, Tuareg and arab nomadic pastoralists [17].

The climate in Manga is Sahelian, with average annual rainfall of $329 \mathrm{~mm}$ (average over 74 years from 1939 to 2013) distributed in a single rainy season from June to September, and August is the wettest month (Figure 2). The average monthly temperature is $28^{\circ} \mathrm{C}$ (over 30 years, from 1983 to 2013) and April and May are the hottest of the year (Figure 2).

The relief comprises a sandy plateau from 300 to $400 \mathrm{~m}$ above sea level, whose upper areas correspond to the rims of shifting sand dunes. The plateau is peppered with basins and lowlands which would seem to derive from the flow network of temporary water courses, once tributaries of Lake Chad. The basins, small oasis depressions around $10 \mathrm{~m}$ in depth, are home to date palms. These basins have three types of hydrological regime in the lowest central section [12]: 1) basins with a high water table (HWTB) at a depth of less than $1.5 \mathrm{~m}, 2$ ) basins with an intermediate water table (IWTB) at a depth of between 1.5 and $4 \mathrm{~m}$ and 3) basins with a deep water table (DWTB) at a depth of over $4 \mathrm{~m}$ [12].

During the long dry season (8 - 9 months, Figure 2), the basins are the only ideal place where humans and animals live side by side in search of the best conditions. During that period, the animals deposit their faeces, which thus maintain soil fertility in the basins [17]. This manure, combined with the shallow depth of the water table, the characteristics of the climate [18] and the texture and chemical composition of the soils [19] create an environment suited to date palm cultivation.

In almost 400 basins with date palms inventoried by Lenormand (1984) [20], Jahiel and Candelier (1991) [21] estimated the date palms in the basins to number 200,000 plants. Male date palms appeared to account for half of the total number of palms in the groves [14], while fewer than 3 male palms are needed for 100 females when artificial pollination is used.

Dates develop in five stages: "Hababouk", end of fruit-set when the small fruit is still with its calyx; "Kimri", from the small fruit stage up to green fruit growth; "Khalal", physiologically ripe and sweet fruit, which turns from green in colour to yellow or red; "Rutab", a fruit whose apex starts to turn from yellow or red to brown or black; "Tamar", a completely ripe fruit whose colour turns from yellow or red to brown or 


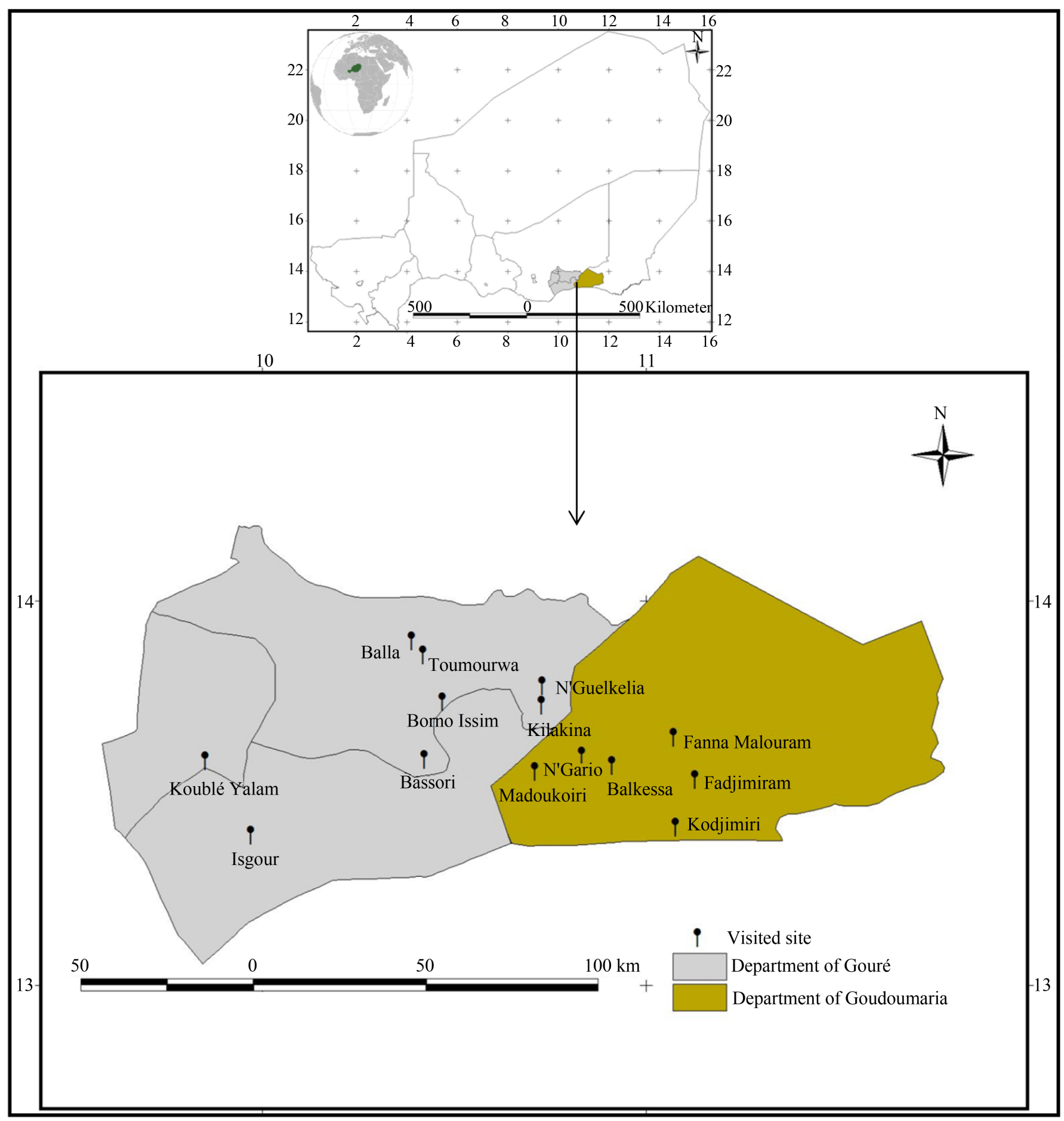

Figure 1. The Manga region in southeastern Niger; the 14 villages surveyed for date palm cultivation (map: Garkoua).

black [22]. In the Manga region, dates are usually harvested at the "Tamar" stage during the first season and at the "Khalal" stage during the second season (rainy season). In order to ensure optimum and profitable production, good practices involve the choice of variety, irrigation, fertilization, sanitation cleaning, pruning of old fronds, 


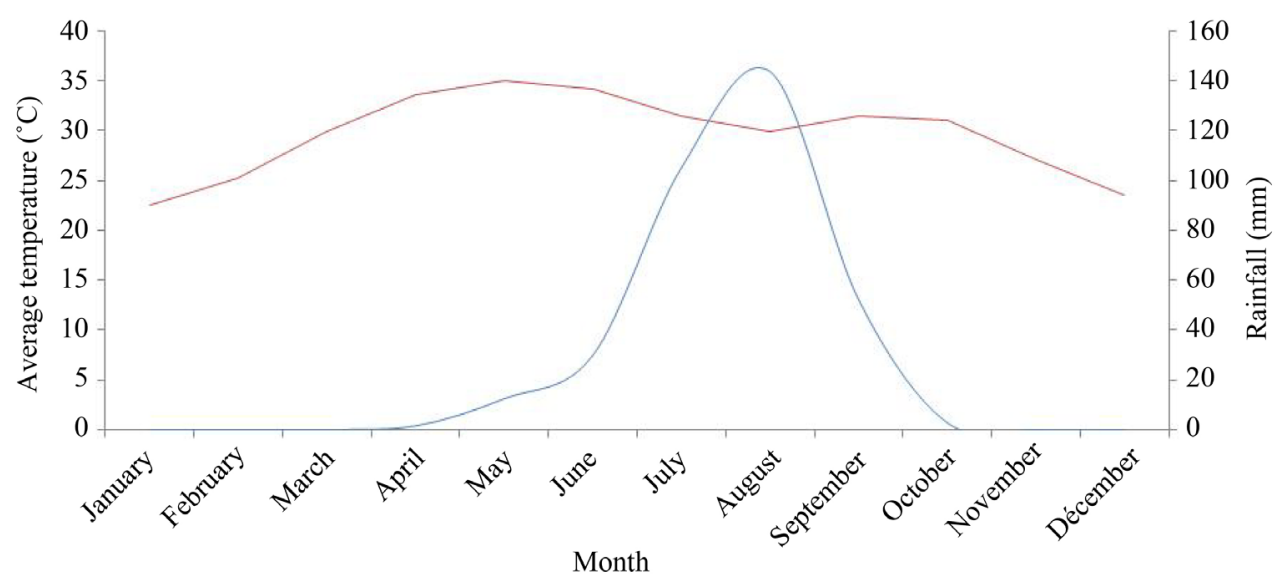

Figure 2. Monthly average temperature trends from 1983 to 2013 (red line) and monthly average rainfall from 1939 to 2013 (blue line).

artificial pollination, thinning of bunches or spikelets, and protection of bunches from pests (insects, birds, mammals; [23]. Nevertheless, apart from pruning, little attention is paid to date palm growing in Manga, as the palms are primarily used to secure land tenure [14].

Our survey covered 14 villages (i.e. around $10 \%$ of the villages in the two departments; Figure 1) representative of the whole Manga region, enabling us to cover the three types of basin. The survey took place in three phases: i) consultation with the population of the village to identify date palm farmers, ii) visit to the palm groves of the person or group to be surveyed (in some cases, all the palms belonged to the founder of the village), iii) data gathering by interviews.

We carried out 30 interviews (on 30 farms) among the date farmers, with an interview corresponding to a meeting with one person or a group of 3 to 6 people. The interview was conducted in the field, in the plots containing the palms, or in the village. The information gathered in each interview was as follows: identity of the basin or village, identity of the producer, date palm seed propagated varieties, cultural practices, date production, the use made of income derived from dates.

\subsection{Data Processing}

The qualitative data (Table 1) were processed by Multiple Correspondence Analyses (MCA) with $\mathrm{R}$ software (version 3.2.0) to characterize the geographical location and categorize the basins according to date palm distinction criteria, and the practices and income uses associated with date palm growing. We used descriptive statistics for some of the calculations comparing production means for the two seasons and the price of dates depending on their provenance.

\section{Results}

\subsection{Local Practices and Knowledge Associated Date Palm}

The first two dimensions of the Multiple Correspondence Analysis (MCA) absorbed 
Table 1. The 14 variables and their modalities for the Multiple Correspondence Analysis (30 interviews in 14 villages, southeastern Niger, 2014).

\begin{tabular}{|c|c|c|}
\hline $\begin{array}{l}\text { Variable } \\
\text { code }\end{array}$ & Variable name & Modalities \\
\hline $\mathrm{P} 1$ & Department & Gouré, Goudoumaria \\
\hline $\mathrm{P} 2$ & Municipality & Gouré, Bouné, Guidiguire, Goudoumaria \\
\hline P3 & Type of basin & HWTB, IWTB, DWTB \\
\hline $\mathrm{P} 4$ & Ethnic group & Hausa, Kanuri, Fulani \\
\hline P5 & Seed propagated variety distinction criteria & $\begin{array}{l}\text { Fruit colour, plant biology, fruit quality, } \\
\text { fruit quality and colour, fruit colour and } \\
\text { biology of the plant }\end{array}$ \\
\hline P6 & Propagation method & $\begin{array}{l}\text { Naturally sown, semi-natural } \\
\text { plantation of suckers }\end{array}$ \\
\hline P7 & Pruning period & Harvest, rest period, harvest and rest period \\
\hline P8 & Pollination & Yes, no \\
\hline P9 & Inflorescence thinning & Yes, no \\
\hline $\mathrm{P} 10$ & Type of organ removed & $\begin{array}{l}\text { A few spikelets, a few inflorescences, } \\
\text { nothing }\end{array}$ \\
\hline P11 & Reason for thinning & Quality, weight reduction, none \\
\hline $\mathrm{P} 12$ & Date production ( $\mathrm{kg} / \mathrm{palm} /$ season $)$ & $50,75,100,150,200,250$ \\
\hline $\mathrm{P} 13$ & Use made of income & $\begin{array}{l}\text { Food, food and clothing, } \\
\text { food and field work }\end{array}$ \\
\hline $\mathrm{P} 14$ & Type of protection against pests & Inflorescence covering, none \\
\hline
\end{tabular}

Type of basin: HWTB, High Water Table Basin, IWTB, Intermediate Water Table Basin, DWTB, Deep Water Table Basin.

$32 \%$ of the variation out of the 30 dimensions of the MCA (Figure 3, P15). Dimension 1 compared the two departments of Manga region (Figure 3, P1). Dimension 2 concerned the different types of basins (Figure 3, P3).

Dimension 1 compared the department of Gouré to the department of Goudoumaria (Figure 3, P1). The farmers in Goudoumaria thinned inflorescences by removing a few spikelets or a few bunches, leading to better quality dates and reducing plant weight to prevent crown toppling (Figure 3, P9, P10 and P11), while those in Gouré were indifferent to this practice. Virtually all the farmers in Goudoumaria carried out artificial pollination, while it was the opposite in Gouré (Figure 3, P8). Artificial pollination was manual and consisted in shaking male inflorescences surrounding female inflorescences and introducing them into the crown of the female plant. The farmers in Goudoumaria protected bunches from pests (insects, birds, bats) much more than those in Gouré (Figure 3, P14). The protection involved using nylon fabric or matting woven from doum palm leaflets to cover the inflorescences. In terms of propagation, the farmers in Goudoumaria used suckers more than those in Gouré (Figure 3, P6). The income from 


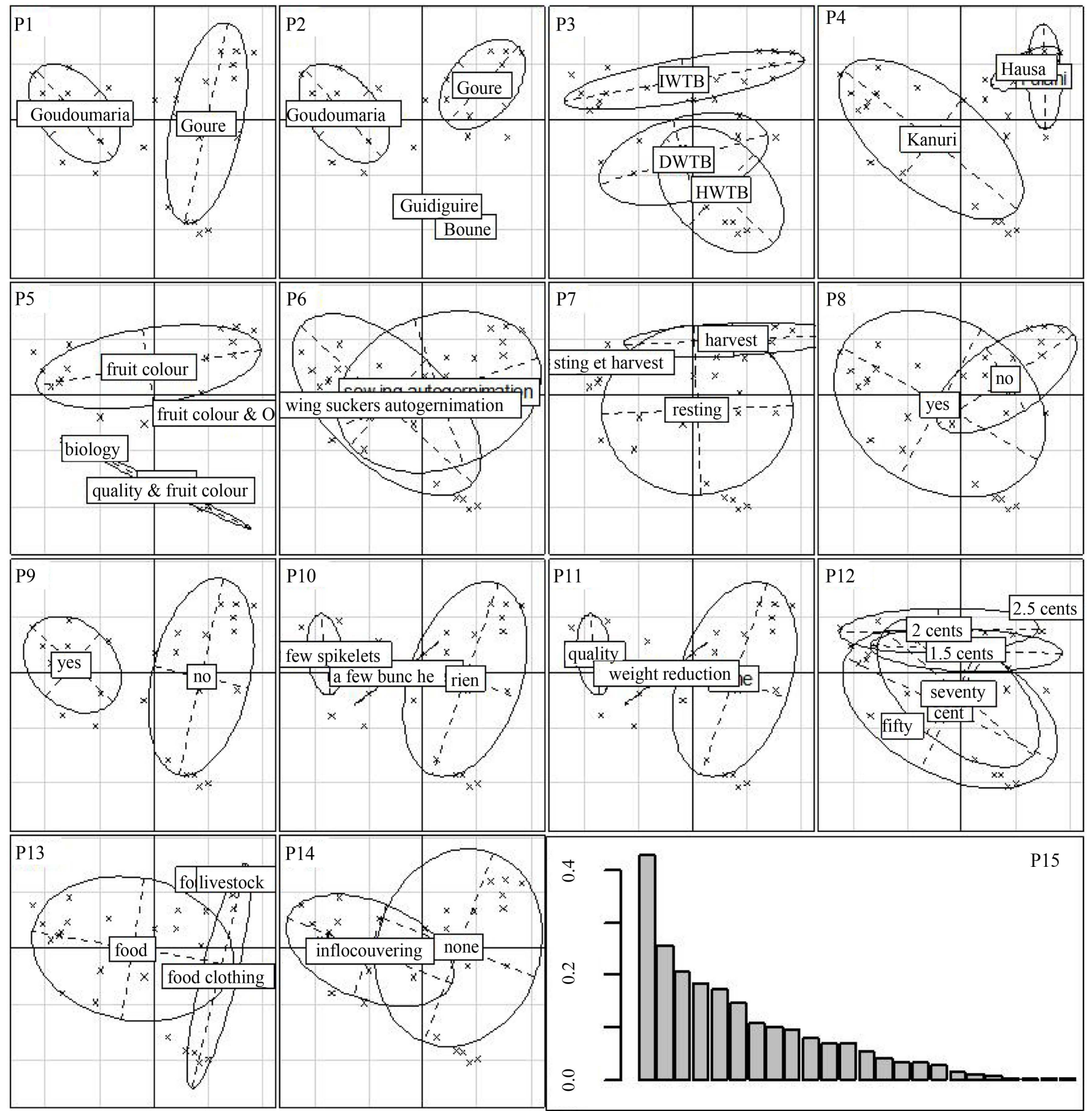

Figure 3. Projection of the 30 surveyed farms growing date palms (Manga region, southeastern Niger, 2014) onto the first two dimensions of the multiple correspondence analysis. Each graph from 1 to 14 represents a projection of the farms according to the modalities of variable $\mathrm{P}$ (see details of the variables in Table 1). Graph 15 shows the diagram for the eigenvalues associated with the 30 dimensions of the MCA).

date sales served solely to buy food and clothing in Goudoumaria, while it was also used to buy livestock and to hire farmer labourers in Gouré (Figure 3, P13).

Dimension 2 compared the intermediate water table basins to the other basins with a 
high or deep water table (Figure 3, P3). The farmers of the intermediate water table basins tended to use the "fruit colour" criterion to identify seed propagated varieties, while the farmers in the other basins also used the quality, biology or origin criteria (Figure 3, P5). Only the farmers in the intermediate water table basins pruned and cleaned their date palms during the harvesting and resting periods (Figure 3, P7). According to the farmers, the date palm was introduced into the high water table basins, which offered ideal conditions for seed germination but, as time went by, the water tables dropped in those basins. Date production per palm and per season was higher in the intermediate water table basins (200 kg on average) than in the other basins (110 kg on average) (Figure 3, P12).

Lastly, the sex ratio (number of male palms compared to the number of female palms) was $32 \%$ in all the basins visited. The farmers had two ways of recognising the sex of the date palm, one by the seeds and one by the seedlings. Any seed with a curved shape, pointed tips and a generally rough appearance would give a female plant and, conversely, any straight seed with a generally smooth appearance would give a male plant (Figure 4(a)). The other way consisted in placing seeds to germinate in the same pit covered with matting woven from leaflets of a palm (Doum palm, Hyphaene thebaica (L.) Mart., date palm): the seedlings for which the first leaves did not manage to pass through the matting were female plants (Figure 4(b)), while those whose leaves passed through the matting were male plants. All the males were usually destroyed and, if needed, only fewer than 30\% were kept.

According to the farmers in Manga, rainfed cereal production outside the basins (millet and sorghum, dietary staples in Manga), only covered 4 months of family food requirements on average. To complete those harvests, date palms were usually intercropped with fruit, cereals and market garden crops, giving rise to palm groves organized

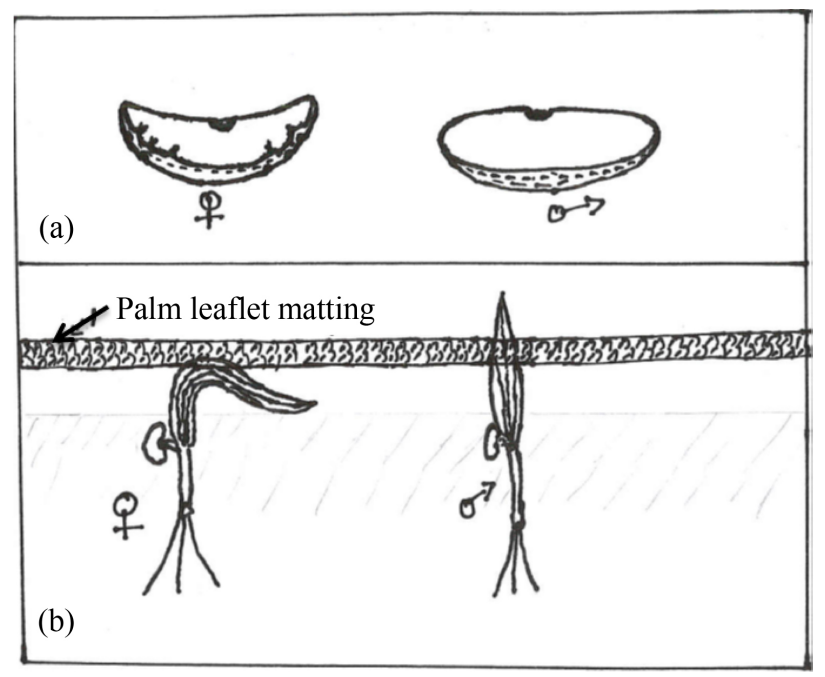

Figure 4. Techniques for early recognition of date palm sex. (a) date palm seeds, female on the left and male on the right.

(b) Date palm seedlings germinated under matting woven from palm leaflets, female on the left and male on the right. 
in 4 strata (Figure 5):

- upper stratum: date palms sometimes with doum palms;

- $2^{\text {nd }}$ stratum, fruit crops: mango, guava, moringa, lemon, baobab, jujube, pawpaw, orange, banana, tamarind;

- $1^{\text {st }}$ stratum: cereals (maize, wheat and sorghum), sugarcane, cassava;

- soil level, market garden crops: cabbage, onion, lettuce, carrot, tomato, potato, chilli pepper, bell pepper, melon, watermelon, squash, sweet potato, aubergine, sorrel, okra.

In this cropping system, the date palms benefited from protection (fencing), irrigation water and the fertilizers applied to the market garden crops in all the groves. On the other hand, when they were in plots without market garden crops, no irrigation or fertilization was provided. In that case, they took up water from the water table and their fertilization came from animals roaming in the basin. In all the basins investigated, the depth of the water table was less than $5 \mathrm{~m}$, Nevertheless, according to the farmers, the date palms competed with the market garden crops and the shade of the palms prevented those crops from growing well.

\subsection{Inventory of Date Palm Seed Propagated Varietes}

We inventoried 19 date palm seed propagated varieties in Manga (Table 2). They were identified from the colour of their fruits at the "Khalal" and "Tamar" stages, sometimes from their quality ("Bordol" which produces large fruits, "Maga" which produces poor quality dates, "Kitila" whose unripe fruit is not astringent), their biology ("Garouda" less susceptible to relative humidity), the origin of the sown seed ("Balma" from Bilma, or "Dan Agadez" from Agadez), and the sex of the palm in question ("Namiji" male palm).

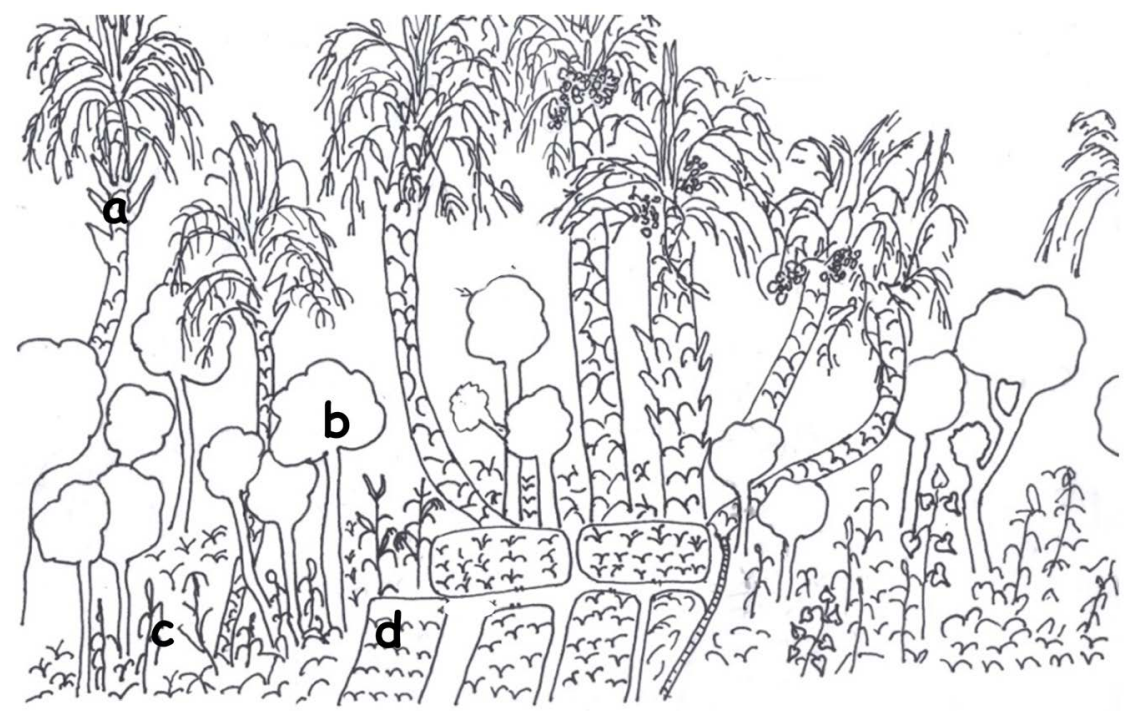

Figure 5. Multi-stratum intercropping of a palm grove in an oasis basin (Manga region, southeastern Niger), (a) date palm (upper stratum), (b) tree crops ( $2^{\text {nd }}$ stratum), (c) cereals ( $1^{\text {st }}$ stratum), (d) market garden crops (soil level). 
Table 2. The 19 date palm seed propagated varieties and their distinctive criteria inventoried in 2014 in 14 villages in the Manga region (southeastern Niger, 2014).

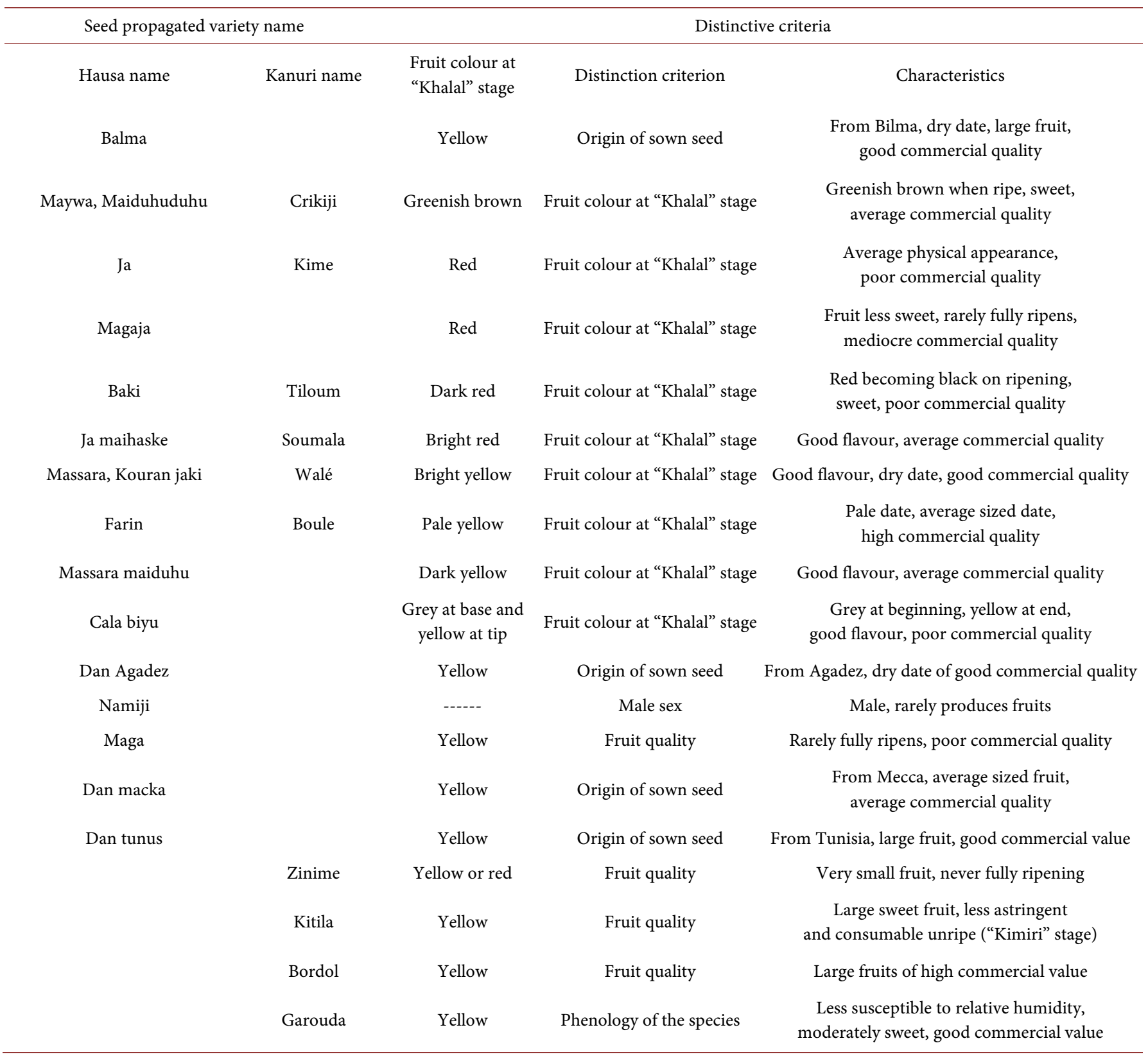

The same seed propagated variety could have two synonymous names in the same language, "Massara" or "Kouranjaki", or in different languages, "Massara" and "Wale". It might also have only one name in one language without a synonym in another, "Balma" and "Zinzime" (Table 2). The names were often preceded by the prefix "Dabino" which designated the date without any seed propagated variety distinction; for example, "Ja" could be called "Dabinoja", "Baki" "Dabinobaki", or "Boule" became "Dabinoboule".

Of the 19 seed propagated varieties in Manga, 12 had yellow fruits, 4 had red fruits, 1 
had greenish brown fruits and 1 other had fruits that were grey at the base and yellow towards the tip (Table 2). In general, the yellow seed propagated varieties had a higher commercial value on the market given the paler appearance of the fruits.

The "Kitila" seed propagated variety produced dates mostly for home consumption. It was the only seed propagated variety whose fruits could be consumed in their unripe stage in full growth before the "Khalal" stage, whereas all the others produced dates that were indigestible at that stage due to the amount of tannin they contained. The "Garouda" seed propagated variety was the only one to produce fruits that fully ripened, i.e. dry on the palm, whatever the rainfall. Despite its average sugar content, the "Garouda" date had a good commercial value during the rainy season because dry dates are rare. To obtain dry dates from the other seed propagated varieties, the farmers cut bunches between the "Khalal" and "Rutab" stages and dried them under thatch shelters where they were hung from the roof, protected from rain, until fully ripe.

On average, 4 seed propagated varieties were grown per village or per basin (Table 3). Each basin was home to at least two seed propagated varieties, except the basin of Koublé yalam, a Fulani village where only one variety, "Massara", was inventoried. The intermediate water table basins (IWTB) had the largest number of seed propagated varieties, apart from the high water table basin (HWTB) of Iskour, which also had 5 seed propagated varieties. The same seed propagated varieties were encountered in both departments, Gouré and Goudoumaria. The "Massara" seed propagated variety was found in 8 of the 14 basins visited (Table 3 ).

In Manga, the "Farin" seed propagated variety produced the dates most appreciated by the farmers. The "Massara" and "Balma" seed propagated varieties in some basins of

Table 3. Varieties grown by village (14 villages, southeastern Niger, 2014).

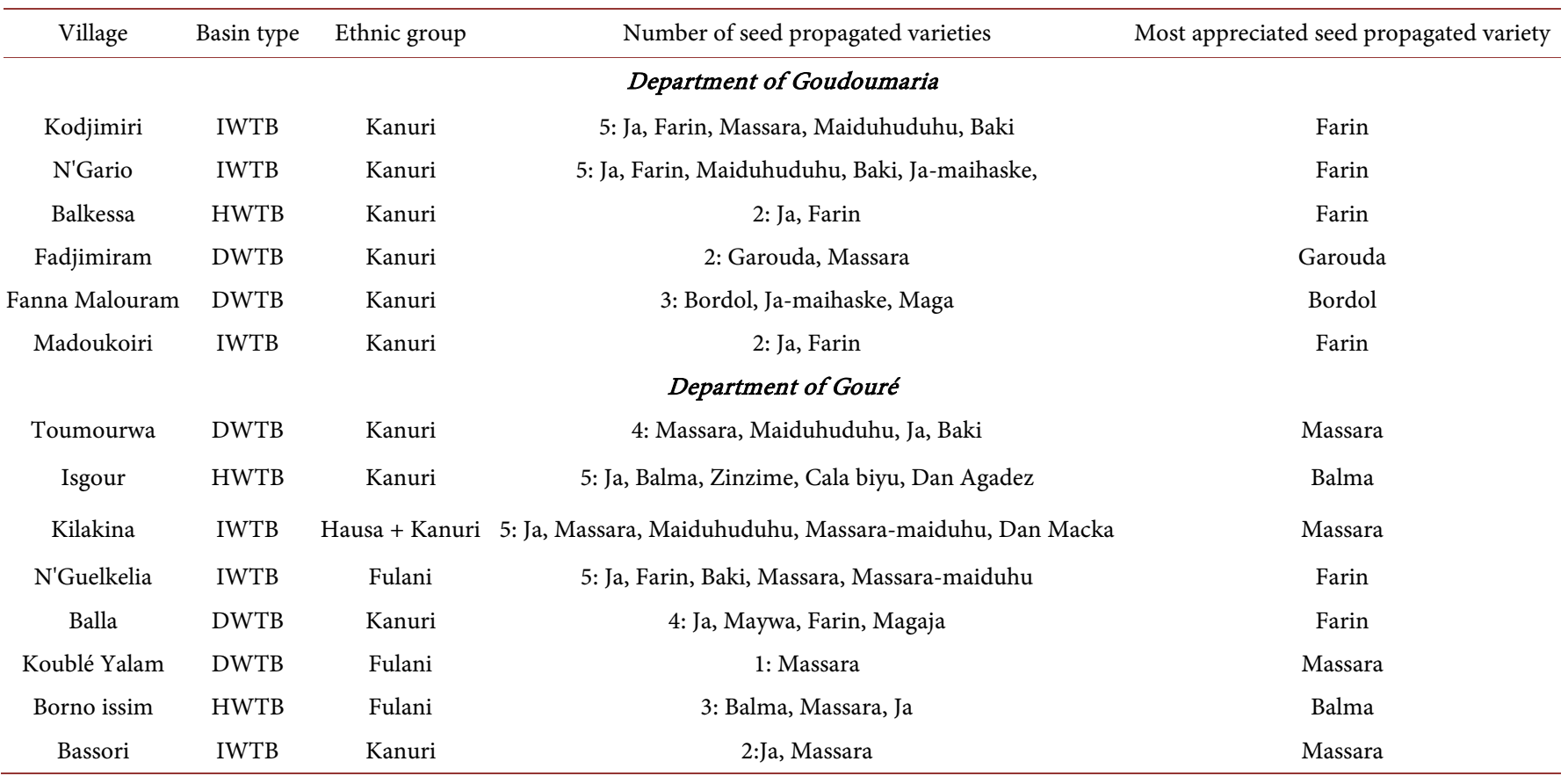

Basin types: HWTB, high water table basin, IWTB, intermediate water table basin, DWTB, deep water table basin. 
the Gouré department, and the "Garouda" and "Bordol" seed propagated varieties in Goudoumaria, produced dates that were also appreciated (Table 3).

\subsection{Date Production Seasons}

The first production season, from September to March (Figure 6), took place in the dry season, with an average $45 \%$ of bearing palms in 2014-2015. On average, a palm produced 6 inflorescences for which all the dates reached full maturity ("Tamar" stage), giving $25 \mathrm{~kg}$ of dry dates.

The second season, from February to July (Figure 6), included the rainy season and $100 \%$ of the mature palms were productive in 2014-2015. On average, a palm produced 12 inflorescences, but the dates rarely reached full maturity due to the rain. Average production per palm was $140 \mathrm{~kg}$ of partially ripe fresh dates. Dry dates were very rare.

\subsection{Date Marketing}

Only $20 \%$ of date production was consumed on-farm, and $80 \%$ went for sale on the local market and in neighbouring Nigeria.

In 2014-2015, on the Boutti local market, the average sale price for a kilo of dry dates was 1060 FCFA $(€ 1.60)$ for the first season and 485 FCFA for the second season (Figure 7). The dates harvested at the "Khalal" or "Rutab" stage (partially ripe), which accounted for virtually all the production in the second season, were sold on average for 50 FCFA per kilo. The dates from the first season sold for more than dates from Bilma (northern Niger) and Libya, but were cheaper than those from Algeria. The dates from the second season were sold for less than those from outside the region.

The low price of dates from the second season (rainy season) was due to their poor quality. On the one hand, the dates did not fully ripen (they remained at the "Khalal" stage) and, on the other hand, the harvest was completed very quickly, in under two weeks, just after the first rainfall. In addition, they were marketed directly, as storage

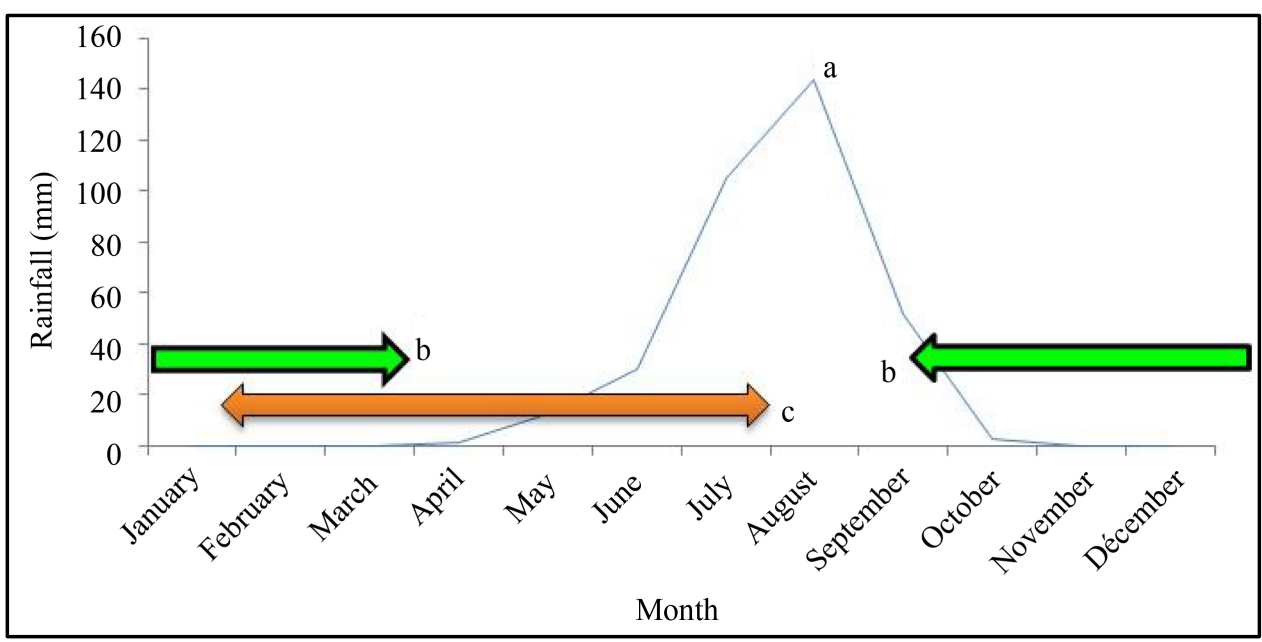

Figure 6. The 2 annual date production seasons in Manga and the monthly average rainfall from 1939 to 2013 in Gouré. (a) Rainfall, (b) $1^{\text {st }}$ season, (c) $2^{\text {nd }}$ season. 


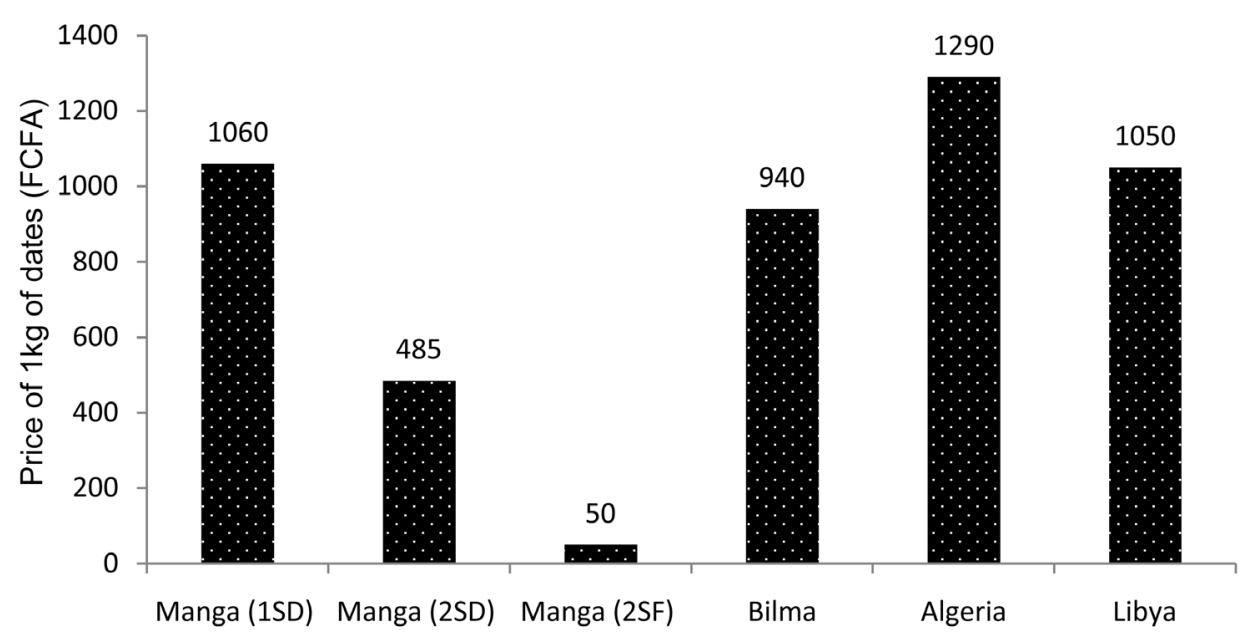

Figure 7. Sale price for dates on the local markets (FCFA/kg, Goudoumaria, southeastern Niger): local dates depending on ripeness stage and the productions season, and dates from outside the region (Bilma, northern Niger, Algeria, Libya) (100 FCFA $=€ 0.15) .1 S D$ : $1^{\text {st }}$ season dried dates; 2SD: $2^{\text {nd }}$ season dried dates; $2 S F: 2^{\text {nd }}$ season fresh dates.

facilities were insufficient. Conversely, the first season (dry season), with less than half of the palms bearing, was more profitable as the dates fully ripened and were sold at twice the price of dried dates from the rainy season.

\section{Discussion}

\subsection{Inventory of Local Seed Propagated Varieties}

Our results showed that 19 date palm seed propagated varieties existed in 2014 in the Manga region of southeastern Niger, whereas the scarce literature on the subject reports far fewer. Indeed, Jahiel and Candelier (1991) only inventoried 3, of which 2 names "Kime" and "Wale" were included in the names we found. A slight contradiction linked to language can be highlighted: unlike what Jahiel and Candelier (1991) stated, the colour "Kimé" in Kanuri means red not yellow, and the colour "Walé" means yellow not red. Abdoussalam and Pasternak (2015) reported six varieties, of which three names "Maiwa", "Ja", "Farin" were included in our inventory, but these six varieties are probably relative to another region close to Manga, the Damagaram region.

Based on the commercial value of the dates, our results revealed that some seed propagated varieties are more appreciated than others. For instance, it may be that a seed propagated variety selection process has taken place, when compared to what was reported by Lenormand (1984) and Jahiel (1989) who described pseudo-date palm cultivation and use of the date palm to secure land tenure. The distinction between male and female seeds, or between male and female seedlings, confirms today the awareness of farmers in the Manga region since the 1970s of the merits of date palm growing reported by Jahiel (1996).

The names of the seed propagated varieties that we identified differed from those inventoried by Abdoussalam and Pasternak (2015) in the traditional date production 
zone in the North of Niger (Bilma, Air, Kawar and Djado) although the languages spoken in the two regions are similar. However, the average number of four seed propagated varieties per basin in the Manga region was lower than that reported by Abdoussalam and Pasternak (2015) in northern Niger, i.e. 7 seed propagated varieties in the Mont Aïr oasis, 13 at Ingall and 10 at Bilma. This difference might be explained by the size of the basin comparatively to that of an oasis. All the seed propagated variety names also differed from the names of the Tunisian, Algerian or Moroccan varieties [24].

\subsection{Local Practices and Knowledge Associated with the Date Palm}

Two of the results, farming practices and the used made of income, could be explained by the positions held by the different ethnic groups in the Manga region of southeastern Niger. On the one hand, farmers in the department of Goudoumaria (Kanuri ethnic group) had a better command of certain cultural practices, notably bunch thinning, hand pollination, palm pruning and inflorescence covering than those in Gouré (Kanuri, Fulani and Hausa ethnic groups). These practices are described in the literature as good practices leading to better quality dates [23] [25]. They are therefore well known in Manga, though they are less developed than in the traditional zones in the North of the country [11]. On the other hand, the income arising from date production is only used to buy food in Goudoumaria, whereas it also serves to buy livestock and clothing and to pay farm labourers in Gouré.

In fact, the Kanuri, who are agropastoralists [26], practise rainfed agriculture exclusively and sometimes sheep fattening. Given the poor seasons seen since the 1970s in the Sahel [18], the Kanuri use almost all the income derived from date cultivation to buy food, to cover nutritional requirements once the rainfed cereal harvests have been exhausted. Consequently, date growing is taking on increasing importance among the Kanuri due to the income it procures. The Fulani, who are generally livestock farmers (Zakari, 1985), show less interest in agriculture to cover their food requirements. Likewise, the Hausa who are traders [26], have trade, in addition to agriculture, which enables them to procure cereal supplies. This explains why the income derived from date growing is also used to buy livestock and pay farm labourers.

We found an improvement in the sex ratio, since it is 32\% today whereas it was $50 \%$ in the 1990s [12]. This improvement doubtless came from the surge in date growing by farmers in Manga since the 1970s [14]. However, some efforts are still needed to return to the recommended sex ratio norm for hand pollination, which is $3 \%$ [22].

Farmers had a particular perception of the consequences of the water requirements of date palms in relation to the hydrological regime of the basin. The farmers in high water table basins, like those in the deep water table basins, did not wish to increase their date palm stand, as they felt that date palms were the main reason for the drop in the water table. For them, the current intermediate water table basins were formerly high water table basins: when the date palm was introduced in those basins, its great evapotranspiration rate [27] [28] would seem to have led to a drop in the water table 
down to the intermediate and even deep stage. In addition, contrary to what was reported by Toutain et al. (1990) [29] and Celette et al. (2008) [30], who suggested that date palms or perennial species live in harmony with seasonal crops (cereals and market garden crops), these farmers believed that date palms competed with market garden crops for water and fertilizer availability. Consequently, they did not take as much care of the current stand as the farmers in the intermediate water table basins who, conversely, had only one ideal: that of enlarging their date palm plantation given the income it generated.

The biology or seed provenance criterion used in distinguishing seed propagated varieties in addition to fruit colour in the high and deep water table basins in no way means that date cultivation practices are better mastered in those basins than in the intermediate water table basins. This is explained by the fact that when farmers in those basins wished to replace a dead palm (rare operation), they often sowed seeds whose fruits they appreciated, found on the market, while regeneration in the intermediate water table basins only involved seeds from the basin in question.

\subsection{Date Production and Marketing}

Our results confirmed the two production seasons, as mentioned by Jahiel and Fortin (1990) in the same region, Munier (1963) [31] in western Mali, and Haury (1982) [32] in western Niger. In addition, in 2014-2015, there were $45 \%$ of bearing palms in the first season, whereas the figure was only $20 \%$ in 1990 [33]. This better result shows that there has been a selection effort made by farmers, linked to the progression in the sex ratio, and also that this double-flowering would also seem to be due to the ageing of the palm groves, as it was seen more on old palms [33].

In 2014-2015, the numbers of inflorescences were identical to those found by Jahiel and Fortin (1990), i.e. 6 inflorescences per palm in the first season and 12 in the second season. Despite the decrease in rainfall since the 1970s [34], the date palms in Manga seem to have kept their development rhythm, which can be explained by the phenollogical plasticity of the species [2] [3] [35].

Date production per palm was six-fold higher in the second season (but with mediocre quality), than in the first season (where quality was better). In addition, the proportion of bearing palms was twice as high in the second season. Consequently, most of the dates in Manga were sold at a paltry price when compared to dates from Bilma (northern Niger), Algeria or Libya. This sale price was linked to a lack of ripeness and poor storage quality. Nevertheless, the high price of dry dates from the first season suggests that the seed propagated varieties in Manga generally produce dates that are much appreciated by the population. The problem to be solved is storage difficulties, for which the solution would seem to lie in breeding varieties that start bearing early or are more humidity-tolerant during ripening, like the "Garouda" seed propagated variety grown in just one of the surveyed villages (the Kanuri village of Fadjimiram, in the department of Goudoumaria). This selection, combined with technical capacity building for farmers, would help to improve the self-subsistence of the local populations, along with their 
incomes, through the existence of greater competitiveness on the local and regional markets.

Our results did not enable us to decide which was the most profitable season as the volume of dry dates in the second season remained very difficult to evaluate. It depended on the early onset (or not) of the rainy season.

\section{Conclusion}

This article describes an original investigation of the local practices and knowledge associated with date palms in the oasis basins of the Manga region in southeastern Niger, along with the inventory of 19 local seed propagated varieties. Today, date palm growing is increasingly considered by farmers as a major source of income, even though there is water competition between this culture and market garden crops growing under palm trees. The other constraint arising is poor date quality in the rainy season, whereas that season is more productive by far than the dry season. Research and sustainable development of date palm cultivation in Sahel, taking into account adaptation to climate change, must rely on date palm improvement in relation with early-production and humidity-tolerant during maturation fruits.

\section{Acknowledgements}

This work was supported by the International Foundation of Science (IFS, grant number D/5695-1; 2014), French embassy in Niger (scholarship) and CIRAD (grant number AI N ${ }^{\circ}$-2014). We thank Mr. Baaré Amadou Chefou executive Secretary of the karkara NGO; Garkoua Sayédi, Director of Hydraulics in Magaria and Col. Hamza Barmou, Director of the Environment, in Gouré, for their logistical support. We also thank Marie Puchon (Karkara NGO Diffa coordinator), Mamane Moussa (Karkara NGO Zinder coordinator), Pr. J. M. Ambouta Karimoune (FA/UAM); Dr Didier Tijani (FA/ UAM) and Elhdj Idi (the village chief of Kilakina).

\section{References}

[1] de Sherbinin, A. (2014) Climate Change Hotspots Mapping: What Have We Learned? Climatic Change, 123, 23-37. http://dx.doi.org/10.1007/s10584-013-0900-7

[2] Arab, L., Kreuzwieser, J., Kruse, J., Zimmer, I., Ache, P., Alfarraj, S., et al. (2016) Acclimation to Heat and Drought-Lessons to Learn from the Date Palm (Phoenix dactylifera). Environmental and Experimental Botany, 125, 20-30. http://dx.doi.org/10.1016/j.envexpbot.2016.01.003

[3] Pintaud, J.C., Ludeña, B., Aberlenc-Bertossi, F., Zehdi, S., Gros-Balthazard, M., Ivorra, S., et al. (2013) Biogeography of the Date Palm (Phoenix dactylifera L., Arecaceae): Insights on the Origin and on the Structure of Modern Diversity. Acta Horticulturae, 994, 19-38.

[4] Routson, R.J. (2012) Conservation of Agro-Biodiversity in Baja California Oases.

[5] de Grenade, R. (2013) Date Palm as a Keystone Species in Baja California Peninsula, Mexico Oases. Journal of Arid Environments, 94, 59-67. http://dx.doi.org/10.1016/j.jaridenv.2013.02.008

[6] Bouguedoura, N. (1979) Contribution à la connaissance du palmier dattier Phoenix 
dactylifera L: étude des productions axillaires, Thèse de Doctorat Troisième Cycle, USTHB, Alger.

[7] Chao, C.T. and Krueger, R.R. (2007) The Date Palm (Phoenix dactylifera L.): Overview of Biology, Uses, and Cultivation. HortScience, 42, 1077-1082.

[8] Zango, O., Littardi, C., Pintaud, J.C., and Rey, H. (2013) Comparative Study of Architecture and Geometry of the Date Palm Male and Females Inflorescences. Acta Horticulturae, 994, 175-192. http://dx.doi.org/10.17660/ActaHortic.2013.994.17

[9] Munier, P. (1973) Le Palmier-Dattier. Maisonneuve \& Larose, Paris.

[10] Daher, A., Adam, H., Chabrillange, N., Collin, M., Mohamed, N., Tregear, J.W., et al. (2010) Cell Cycle Arrest Characterizes the Transition from a Bisexual Floral Bud to a Unisexual Flower in Phoenix dactylifera. Annals of Botany, 106, 255-266. http://dx.doi.org/10.1093/aob/mcq103

[11] Abdoussalam, S. and Pasternak, D. (2015) Date Palm Status and Perspective in Niger. In: Al-Khayri, J.M., Jain, S.M. and Johnson, D.V., Eds., Date Palm Genetic Resources and Utilization, Springer Netherlands, Dordrecht, 387-409. http://dx.doi.org/10.1007/978-94-017-9694-1_11

[12] Jahiel, M. (1996) Phénologie d'un arbre méditerranéen acclimaté en région tropicale : le dattier au sud du Niger et son appropriation par la Société Manga. Université de Montpellier II, Montpellier.

[13] Chillio, L. (1994) Une histoire des famines au Sahel. Étude des grandes crises alimentaires (XIXème-XXème siècles). Boureima Alpha Gado, L'Harmattan, 201 p. http://apad.revues.org/2363

[14] Jahiel, M. and Blay, J.C. (1994) La double floraison du palmier dattier dans le Sud-est du Niger. Fruits, 49, 111-120.

[15] Bhansali, R.R. (2010) Date Palm Cultivation in the Changing Scenario of Indian Arid Zones: Challenges and Prospects. In: Ramawat, K.G., Ed., Desert Plants, Springer Berlin Heidelberg, Berlin, Heidelberg, 423-459. http://dx.doi.org/10.1007/978-3-642-02550-1_20

[16] Jahiel, M. and Blay, J.C. (1994) La double floraison du palmier dattier dans le Sud-est du Niger. Fruits, 49, 111-120.

[17] Thébaud, B. and Batterbury, S. (2001) Sahel Pastoralists: Opportunism, Struggle, Conflict and Negotiation. A Case Study from Eastern Niger. Global Environmental Change, 11, 6978. http://dx.doi.org/10.1016/S0959-3780(00)00046-7

[18] Ozer, P., Hountondji, Y., Niang, A.J., Karimoune, S., Laminou Manzo, O. and Salmon, M. (2010) Désertification au Sahel: historique et perspectives. Bulletin de La Société Géographique de Liège, 54, 69-84.

[19] Ambouta, K.J.M. (2006) Rapport de caractérisation des sols des cuvettes et bas-fonds de la zone d'intervention du PLECO : possibilités d'exploitation agricole et de valorisation. Projet de Lutte Contre l'Ensablement des Cuvettes Oasiennes dans les Départements de Gouré et de Maïné-soroa (PLECO), Gouré et Mainée.

[20] Lenormand, C. (1984) Mission d'évaluation des potentialités phénicicoles de la région du Manga.

[21] Jahiel, M. and Candelier, P. (1991) Le palmier dattier dans le Sud-Est du Niger (cas des cuvettes de Maïné-Soroa). Fruits, 46, 83-92.

[22] Zaid, A. and De Wet, P.F. (1999) Chapter I Botanical and Systematic Description of Date Palm. FAO Plant Production and Protection Papers 1-28.

[23] Zaid, A. and de Wet, P.F. (2002) Pollination and Bunch Management. In: Zaid, A., Ed., 
Date Palm Cultivation, Chapter 8, FAO, Plant Production and Protection, 156.

[24] Mohamed Ahmed, M.V.O., Bouna, Z.E.O., Mohamed Lemine, F.M., Djeh, T.K.O., Mokhtar, T. and Mohamed Salem, A.O. (2011) Use of Multivariate Analysis to Assess Phenotypic Diversity of Date Palm (Phoenix dactylifera L.) Cultivars. Scientia Horti- culturae, 127, 367-371. http://dx.doi.org/10.1016/j.scienta.2010.11.011

[25] Nixon, R.W. and Carpenter, J.B. (1978) Growing Dates in the United States. United States Department of Agriculture Bulletin No. 207, US Department of Agriculture, Washington DC.

[26] Zakari, M. (1985) Contribution à l'histoire des populations du Sud-Est nigérien. Le cas du Mangari (XVI-XIXs).

[27] Adil, M., Samia, H., Sakher, M., El Hafed, K., Naima, K., Kawther, L., et al. (2015) Date Palm (Phoenix dactylifera L.) Irrigation Water Requirements as Affected by Salinity in Oued Righ Conditions, North Eastern Sahara, Algeria. Asian Journal of Crop Science, 7, 174-185. http://dx.doi.org/10.3923/ajcs.2015.174.185

[28] Tripler, E., Shani, U., Mualem, Y. and Ben-Gal, A. (2011) Long-Term Growth, Water Consumption and Yield of Date Palm as a Function of Salinity. Agricultural Water Management, 99, 128-134. http://dx.doi.org/10.1016/j.agwat.2011.06.010

[29] Toutain, G., Dollé, V. and Ferry, M. (1989) Situation des systèmes oasiens en régions chaudes. Cahiers de la Recherche Développement, 3-14.

[30] Celette, F., Gaudin, R. and Gary, C. (2008) Spatial and Temporal Changes to the Water Regime of a Mediterranean Vineyard Due to the Adoption of Cover Cropping. European Journal of Agronomy, 29, 153-162. http://dx.doi.org/10.1016/j.eja.2008.04.007

[31] Munier, P.M. (1963) Prospection phenicicole du territoires de la Republique du Niger. Institut français de recherches fruitières outre-mer.

[32] Haury, A. (1982) Etude du comportement du palmier-dattier au Niger : Bonkoukou, Dallol Bosso. Fruits, 37, 627-633.

[33] Jahiel, M. and Fortin, L. (1990) La double floraison du palmier dattier dans le Sud-Est du Niger. Fruits, 45, 615-621.

[34] Panthou, G., Vischel, T. and Lebel, T. (2014) Recent Trends in the Regime of Extreme Rainfall in the Central Sahel. International Journal of Climatology, 34, 3998-4006. http://dx.doi.org/10.1002/joc.3984

[35] Chandra, A., Chandra, A., Gupta, I.C., et al. (1992) Datepalm Research in Thar Desert. Scientific Publishers, Jodhpur. 
Submit or recommend next manuscript to SCIRP and we will provide best service for you:

Accepting pre-submission inquiries through Email, Facebook, LinkedIn, Twitter, etc. A wide selection of journals (inclusive of 9 subjects, more than 200 journals)

Providing 24-hour high-quality service

User-friendly online submission system

Fair and swift peer-review system

Efficient typesetting and proofreading procedure

Display of the result of downloads and visits, as well as the number of cited articles

Maximum dissemination of your research work

Submit your manuscript at: http://papersubmission.scirp.org/ 